УAK 874.14.56

\author{
T. Busarieva, \\ $\mathrm{PhD}$ in Economics, Associate Professor, Specialist for ensuring \\ the work of the Supervisory Board of NPC "Ukrenergo" \\ ORCID ID: 0000-0003-3863-4511
}

DOI: $10.32702 / 2306-6792.2021 .11 .34$

\title{
WAYS OF TRANSNATIONALIZATION OF NATIONAL UKRAINIAN COMPANIES
}

\author{
Т. Г. Бусарєва, \\ к. е. н., доцент, фахівець по забезпеченню роботи, Наглядова Рада НЕК "Укренерго"
}

\section{ШАЯХИ ТРАНСНАЦІОНААІЗАЦІЇ НАЦІОНААЬНИХ КОМПАНІЙ УКРАЇНИ}

The modern domestic economy is in a new qualitative state, which is associated with changing economic conditions due to: the introduction of new, high levels of technology in production, expanding information space, capital mobility, increasing the role of creativity, creative work, increasing the role of theoretical knowledge. At the beginning of the XXI century it can be argued that the formation of Ukrainian corporations can become one of the strategic priorities of public policy, which, provided the appropriate external environment, will increase the competitiveness of the economy and through the exclusive capabilities of national corporations. development of Ukrainian economic structures, internationalization of their production and capital, integration of Ukraine into the world economy, its participation in global transformation processes. In order to interact with TNCs both in Ukraine and on world markets, it is necessary to create our own, Ukrainian transnational structures, as China, Russia, India, Indonesia, Mexico, Venezuela and others have done before. The experience of these states shows that national capital is able to compete with TNCs only if it is structured into strong financial and industrial entities that operate in accordance with international counterparts and are able to pursue an active foreign economic policy.

Thus, the creation of Ukrainian TNCs will contribute to: protection of national economic interests; will promote the further development of Ukrainian economic structures, the internationalization of their production and capital, the integration of Ukraine into the world economy, its participation in global and transformational processes; will promote the introduction of new technologies and allow to modernize production; to ensure the employment of the local population, while increasing wages and improving the social security of workers, etc. It can be argued that the formation of Ukrainian TNCs can become one of the strategic priorities of state policy, which, provided the appropriate external environment, will increase the competitiveness of the economy and through the exclusive capabilities of national TNCs will protect national economic interests, promote the development of Ukrainian economic structures., internationalization of their production and capital, integration of Ukraine into the world economy, its participation in global transformation processes.

Сучасна вітчизняна економіка знаходиться в новому якісному стані, який пов'язаний зі зміною умов господарювання, обумовленого: впроваАженням нових, високого рівня технологій у виробництво, розширенням інформаційного простору, мобільністю капіталу, підвищенням ролі креативності, творчої праці, зростанням ролі теоретичних знань. На початку XXI століття можна стверджувати, що формування українських корпорацій може стати одним із стратегічних пріоритетів державної політики, яка за умови створення відповідного зовнішнього середовища, сприятиме підвищенню конкурентоспроможності економіки і за рахунок екскдюзивних можливостей національних корпорацій Аасть змогу певною мірою захистити національні економічні інтереси, сприятиме подальшому розвитку українських господарських структур, інтернаціоналізації ї виробництва і капіталу, інтеграції України в світову економіку, ііі участі в глобальних трансформаційних процесах. Аля взаємодії з ТНК як в Україні, так і на світових ринках необхіАно створити власні, українські транснаціональні структури, як це робили раніше Китай, Росія, Індія, Індонезія, Мексика, Венесуела та інші. АосвіА цих держав показує, що національний капітал зАатний конкурувати 3 ТНК лише в тому випадку, якщо він структурований у потужні фінансові та промислові суб'єкти, які діють віАповідно до міжнародних аналогів і зАатні проводити активну зовнішньоекономічну політику.

Таким чином, створення українських ТНК сприятиме: захисту національних економічних інтересів; сприятиме подальшому розвитку українських економічних структур, інтернаціоналізації їх виробництва та капіталу, інтеграції України у світову економіку, ії участі у глобальних та трансформаційних процесах; сприятиме впровадженню нових технологій і дозволить модернізувати виробництво; забезпечити зайнятість місцевого населення, одночасно підвищуючи заробітну плату та покращуючи соціальне забезпечення робітників тощо. Можна стверджувати, що формування українських ТНК може стати одним із стратегічних пріоритетів державної політики, яка, за умови створення відповідного зовнішнього середовища, сприятиме підвищенню конкурентоспроможності економіки і за рахунок ек- 
склюзивних можливостей національних ТНК дозволить певною мірою захистити національні економічні інтереси, сприятиме розвитку розвитку українських господарських структур, інтернаціоналізації ї виробництва і капіталу, інтеграції України в світову економіку, їі участі в глобальних трансформаційних процесах.

Key words: transnationalization, knowledge economy, national companies, globalization, economic development.

Ключові слова: трансначіоналізачіл, економіка знань, начіональні компанії, глобалізачія, економічний розвиток.

\section{THE PROBLEM SOLVING}

The formation of the economy at the regional level as a fundamentally new system of socioeconomic system is due to the special role of knowledge in modern civilization. The development of a regional economy based on knowledge is due to a number of factors: human, which determines the socio-economic relations; technological, which is intensively developing under the influence of science; information that generates, redistributes to accumulates new knowledge. Thus, only a systematic and comprehensive modernization of the entire economy of the regions can ensure the transition of Ukraine to a qualitatively new level of civilizational development. Today, the fundamental resource of regional development is knowledge, which becomes a key factor in social development, contributes to achieving the goals of sustainable regional economic development, improving social welfare, promoting social harmony. Modern problems of economic development of the regions of Ukraine are associated with the formation of a new paradigm of scientific and technological development. The components of the new economy are innovation, growth of social orientation of the created technologies, the general nature of accessibility and use of knowledge, technologies, innovative products and services. That is, the longterm competitiveness of the regional economy is ensured by the transition to a "knowledge economy", the priorities of which are the development and dissemination of information technology, as well as the development and widespread implementation of innovations and investments in human capital formation. Building a knowledge-based economy in Ukraine is determined by the main way to increase the competitiveness of both individual regions and countries, ensuring a new quality of life. The region's ability to produce knowledge, including scientific knowledge, implement it and use it effectively to achieve effective socio-economic development are now becoming the main factors that ensure positive dynamics of economic development of regions along with traditional sources - investment and human labor. That's why in the terms of the formation of the knowledge economy it is necessary to come up with the ways of transnationalization of the national companies of Ukraine.

\section{ANALYSIS OF RECENT RESEARCH AND PUBLICATIONS}

Among authors, whose works largely represent the ways of transnationalization of the national companies it is necessary to mention such as D. Bell, T. Gryhiles, U. Dyzard, J. Martine, E. Masudu, F. Makhlup, E. Mansfield, R. Nelson, I. Nikolov, T. Stouniere, E. Toffler, J. Schumpeter, J. Ellul, A.B. and Anchishkina, L.L. Veger, L.M. Gatovsky, L.S. Glyazer. Therefor there are some aspects of the specific characteristics of the formation the ways how to make the national companies go into the world market and to become transnational are still not solved.

The aim of the article is to analyze the ways of transnationalization of national Ukrainian companies.

\section{PRESENTATION OF THE MAIN MATERIAL}

In the formation of the knowledge economy necessary from our point of view is the transnationalization of national companies and the globalization of national production. That is why it is expedient to divide the process of transnationalization of Ukrainian corporations into several stages, without going through which companies cannot be considered truly transnational. From our point of view, it is expedient to single out 6 stages of transnationalization of Ukrainian TNCs, in particular:

At the first stage, the company has the prerequisites for transnationalization, which can act as:

- first, the presence of this company specific (unique) advantages over national firms of the host country. Such advantages are: technological advantages (possibility of introduction of a new product, or new production process); advantages of international production (the ability to achieve the effect of scale from the location of individual links in the production chain in different countries); managerial advantages (the ability of company managers to develop and implement a global strategy); benefits of unique access to raw material sources; 
- secondly, the emergence of a situation in which companies are more profitable to use these benefits through the transnationalization of activities, rather than through the export of goods, services and technologies by domestic firms;

- thirdly, it is through the transnationalization of the company that it can make more efficient use of its unique resources. If the three preconditions coincide at the same time, the transnationalization of the national company will be considered expedient;

At the second stage, a comprehensive rehabilitation of the existing corporate structure (which is necessary for most Ukrainian corporate entities), the measures of which are listed in the table.

The first aspect of such recovery is the organizational and legal analysis of the reformed company, the isolation of a competitive area and structure. The technological aspect of economic recovery of corporate finance involves, first, a review of existing research achievements. Secondly, it is necessary to make decisions about a promising production structure that meets market requirements. Without the implementation of a sound strategy and program of functioning of the competitive part of the corporation, it is difficult to count on real financial recovery [1, p. 23-28].

Among the measures of state support aimed at restructuring and reforming corporate structures, we can highlight the following.

- First, the expansion of the domestic commodity market and its protection against the expansion of foreign competitors.

- Secondly, the restructuring of debts and assets of enterprises.

- Thirdly, stimulating the development of the stock market in relation to investment-attractive industrial regions, industries, enterprises.

- Fourth, a more active influence federal authorities for industrial development in such aspects as antitrust, anti-dumping policies, product certification, licensing activities and so on. p.

- Fifth, strengthening investment policy in the industrial sector, which includes providing guarantees to private investors, developing ratings of investment attractiveness of firms and enterprises, streamlining the regime of import and export of foreign capital and wider attraction of foreign loans based on information about investment projects to foreign investors.

First of all, it is necessary to take into account the fact that almost all countries with stable growth in their economies have pursued an active policy of supporting the processes of creating financial-industrial corporate associations. As a result, in the United States, about 100 of the largest corporations produce $60 \%$ of GDP, create about
$50 \%$ of jobs, carry out $90 \%$ of research and development. In Japan, 5 leading corporations control up to $80 \%$ of the national market, etc.

Among the reasons that hinder the formation of transnational corporations on the basis of Ukrainian financial and industrial groups, there are three key ones. The first is the unregulation of joint-stock relations within corporate entities, the low level of consolidation of ownership, the underdevelopment of holding principles of organization of joint activities. Management companies function as advisory services, not as centers of strategic planning or coordination of financial flows.

The second problem is the limited investment opportunities. Insufficient investment potential for the implementation of large production modernization projects is observed even in the groups formed around the leading Ukrainian banks.

The third problem can be considered the low quality of corporate governance. Within the framework of this problem, mistakes in the selection of FIG participants, lack of preliminary development of the internal corporate strategy, and programs for its implementation are highlighted. Long-term integration and cooperation are currently not widespread enough, and many FIG agreements are general in nature and do not involve commitments from the parties [2, p. 44-48].

However, the most successful corporate structures (in particular, FIGs) created by banks, financial and trading companies, are characterized by the following general features.

First, they have a desire for the optimal ratio of financial and industrial components. Secondly, the presence within the considered structures of large successful industrial enterprises with great export potential. In most cases, these include oil, gas, energy companies, metallurgical enterprises, as well as enterprises of the military-industrial complex. Virtually all corporate education seeks to diversify and expand in their areas of the economy. Third, there is the penetration of leading FIGs in the industry that meet the demand of domestic individual consumers (food and light industry, imports of food and consumer goods, trade in petroleum products, production of building materials). This is due to the need to obtain the maximum possible rate of return. Fourth, there is an expansion (still on a small scale) in high-tech industries (currently unprofitable, but determine the prospects for economic growth in the future electronics, telecommunications, etc.). Fifth, there is a desire to find in foreign markets not only consumers of their products and counterparties to current activities, but also strategic investors and partners.

Thus, by focusing on the most successful Ukrainian corporate entities, in the implementation 
of measures of loyal state support, it is possible to rehabilitate existing corporate structures in the Ukrainian economy and move them to the next stage in the process of their transnationalization.

In the third stage, the corporation must be given the official status of a transnational or interstate financial-industrial group.

Measures to modify Ukrainian corporations are of particular importance, as currently most of the functioning Ukrainian corporate entities (including transnational ones) are in fact unregistered financial and industrial groups. In this situation, they face some difficulties in entering the world market, as their lack of officially recognized corporate status (which are considered partners of the state in implementing the strategy of increasing resilience and growth of the Ukrainian economy) reduces their attractiveness to foreign partners. Transparency of the processes of formation and functioning of corporate entities is extremely important for foreign partners, especially if these aspects are guaranteed by state participation [3, p. 14-17].

The state does not necessarily have to participate in the capital of FIGs, it must in some way certify the fact of creating a corporate structure and guarantee the "purity" of its origin. In this aspect, an extremely important issue is the state's recognition of the most successful corporate entities (including transnational) and giving them the status of official financial and industrial groups. The most significant is the granting of certain preferences, due to which the most successful realization of both corporate and national interests of the country of the corporation's base within the whole world economy should be achieved. Thus, the highest priority of the state should be not so much the desire to form new financial and industrial groups through agreements (which often remain only on paper), as stimulating the activities of leaders among Ukrainian corporations with manda tory coordination of corporate interests and the national economy.. The development of Ukrainian transnational corporations can, based on these assumptions, be carried out in two ways.

First, through the formation of powerful national corporations (formal and informal FIGs) with their further expansion within the world economy.

Secondly, on the basis of the existing system of division of labor and the corresponding cooperation of production between the CIS countries by creating transnational and interstate FIGs with the participation of financial and economic resources of partner.

At the initial stage of transnationalization of corporations, a certain advantage may belong to the second approach. This is partly due to the lack of own resources for the rapid creation of powerful integrated corporate structures. Moreover, the creation of TFPG and MFPG helps to support the existing cooperation of industrial production of economic entities of the CIS countries, as well as the restoration and development of integration processes between them.

At the fourth stage of transnationalization of Ukrainian corporations, the host country is selected. The form of transnationalization of the corporation is determined on the basis of the ratio of the attractiveness of the host country and the regime of promoting the introduction of TNCs into its economy. Forms of expansion of TNCs are: foreign direct investment, which results in associates, subsidiaries and branches (in the form of a permanent representative office or office of a foreign investor, a private enterprise or "Joint Venture" (joint venture) between a foreign investor and one or more firms, land, buildings (except state-owned) and / or real estate (equipment) or items owned by a foreign resident, as well as movable property or equipment (vessels, aircraft, drilling platforms) operating outside foreign investor countries). All the above forms of foreign divisions of TNCs are a type of relationship of parent and subsidiary in terms of ownership. However, at the present stage of development of transnational corporations, the type of interconnection from the line of sphere of activity is becoming more and more widespread. This type includes licensing, management, lease agreements, industrial cooperation, contracts, franchising, engineering, consulting.

Thus, around the parent company of TNCs should be created economic zone of ownership of various kinds, consisting of foreign units with varying degrees of control both in terms of ownership and in terms of scope. Subdivisions related to the parent company in the field of activity are not formally part of TNCs, and their performance indicators are not reflected in the consolidated balance sheets of the corporation, however, they make a significant contribution to the results of TNCs as a whole and are virtually uncontrollable. by the state authorities of the host countries [4, p. 4-9].

Production activities can be carried out abroad, because the import of certain goods and services into the country may be difficult due to customs restrictions, as well as due to the specifics of the product (for example, maintenance of any equipment is possible only at the base). Thus, instead of increasing production in the home country of the parent company for the purpose of further export of products, in the host countries a network of subsidiaries of different orientations (production, 
sales, service, etc.) is created. In this case, this form of expansion is better than increasing exports, which should be confirmed by comparing the effectiveness of different forms of expansion.

The choice of the host country in the process of transnationalization of the corporation is based on the principle of criteria selection, or on the basis of a rating assessment of the potential of potential candidates. The choice must be made in favor of the country where the most complete realization of the corporation's goals is possible. In the case of foreign direct investment, the assessment of the investment climate in the host country, the mode of attracting foreign direct investment is taken as a basis.

At the fifth stage of transnationalization of Ukrainian corporations, their activities should have a pronounced international character with all the features - international production, international sales, service, marketing, etc. As a result of the global nature of the corporation will receive specific competitive advantages if it uses certain techniques and technologies in the process of its operation [5, p. 36-41].

Taking advantage of the global scale of activity ensures the resilience of TNCs to crises in the world economy and the national economy (host country or host country). Stability of TNCs means longterm achievement of a stable result of activity (absence of sharp fluctuations of indicators of profitability, profitability, etc.). It is international commercial operations that increase the resilience of a corporation. The mechanism of this phenomenon is to cover the losses of corporate units in some countries by the profits of units in others. Thus, thanks to the profits received by some foreign units, TNCs can minimize losses incurred by others or the parent company in the home country.

Consider in more detail the methods and technologies by which a corporation in the process of transnationalization of its activities can achieve higher sustainability compared to national corporate entities.

One way to increase the sustainability of TNCs is to diversify production within the corporation. As a result of diversification, subsidiaries of TNCs are declining to varying degrees due to the unequal impact of the crisis on their operations in different countries. Diversification is carried out not only by country, but also by type of products, which also improves the results of the anti-crisis strategy.

The presence of production and other branches (divisions) abroad allows TNCs to use such a way to strengthen the position of TNCs in the world economy, as currency speculation. However, the currency speculations of TNCs differ significantly from those in exchange activities, because they are directly integrated with the production and trading activities of multinational corporations. With the existence of numerous branches abroad, which accumulate significant resources (including credit and financial), some divisions of the corporation benefit from favorable changes in exchange rates. At the same time, no real loss is observed in other branches. For example, the revenue of American branches of Ukrainian TNCs comes in dollars. It is obvious that the growth of the dollar against the hryvnia will increase revenues (revenue remains unchanged), when expressed in national currencies. American units, in turn, will not suffer losses. The opposite change in the dollar will be unfavorable only formally, as when converted into rubles the size of profits of subsidiaries will decrease. However, in reality, transactions were carried out in dollars and revenue, expressed in US currencies, did not decrease. Cash flows, respectively, can not be sent to Ukraine, and reinvest profits abroad. Thus, a multinational corporation due to the presence of branches in different countries can carry out profitable currency speculation by pumping free financial resources between countries at the time of the most favorable exchange rates.

However, in times of acute crisis, changes in exchange rates may not always be beneficial to TNCs. Therefore, the schemes of redistribution of funds between branches, in fact, can be implemented in the form of intra-corporate loans in order to obtain foreign exchange earnings. At any time, certain branches of TNCs will be located in countries with rising exchange rates and act as socalled creditors, who invest in the total financial resources of the corporation.

Similarly, a multinational corporation has the right to apply differences in interest rates and inflation rates of the home countries of the TNCs and the parent company. Thus, with a high level of inflation in the home country, the nominal profits of the branch grow, and can be transferred to the accounts of the parent company abroad. And since the devaluation of money within the country does not always cause a fall in the exchange rate, the profits of the branch can be converted into a more stable currency.

The more stable position of transnational corporations in times of crisis has a financial basis. The reason for this lies in the functioning of the corporation as a single integrated mechanism. That is, the benefits will arise only at the level of TNCs as a whole, while some of its branches may be in a worse position.

As for the direct production activities of TNCs, such a stabilization strategy has little effect on this 
area, as branches set output in accordance with the favorable conditions for their activities. And the overall stabilization effect is due to the branched structure of transnational corporations, some components of which are affected by the crisis, and some, conversely, are in a favorable economic environment.

A similar situation arises with changes in exchange rates, differences in inflation, interest rates. TNCs do not pre-target the scale of production on certain fluctuations in exchange rates, but in moments of the most favorable exchange rates, the corporation produces the optimal redistribution of resources. Due to its international structure, TNCs have the ability to make such a redistribution at almost any time.

Consider the technologies used to move credit and financial resources within multinational corporations in order to stabilize their functioning. Their relocation within TNCs, as a rule, occurs using the following technological techniques: direct capital transfer, transfer of dividends, payment for services rendered, payment of licenses, the use of transfer pricing in intra-corporate trade, intracorporate lending and insurance.

Of these methods of transferring financial resources, only the direct transfer of capital and the transfer of dividends are adequately reflected in the reports of the multinational corporation. They are used in periods of relatively favorable conditions, when the corporation does not need to hide the real goals of moving financial resources. In this situation, the transfer of capital to foreign countries will be associated with the launch of an investment project (opening a branch or expansion into new markets), and the transfer of dividend payments from foreign branches is considered a normal result of their activities.

When there is a threat to sustainability, transnational corporations resort to the use of so-called covert methods of redistribution of credit and financial resources, which look like the exchange of goods (services) between branches of the corporation. The practice of transfer pricing in trade between branches of TNCs in different countries is the most common method. The essence of this operation is that the corporation itself sells the goods, and itself buys it, resulting in a mere countermovement of goods (services) and payments for them between units of the multinational corporation. Both the goods and the monetary resources remain the property of the company.

In practice, this technique is used as follows. To transfer funds from a country with a high level of taxation to the offshore zone, you simply need to sell the goods of the branch, which is offshore, at a reduced price or buy products from an offshore company at an inflated price. The unit, which is located in an area with high taxation, suffers losses as a result of these operations, but this will maximize the real profits of the corporation as a whole.

The exchange of services, intra-corporate licenses is carried out by a similar mechanism and has a number of advantages, because to a lesser extent than the establishment of understated (inflated) prices, attracts the attention of regulatory authorities.

However, almost all offshore countries (Bahamas, Antilles, etc.), in whose economy it is unprofitable to fully invest the profits. Therefore, corporations find a way out of this situation through lending operations, as a result of which the offshore divisions of the corporation provide funds to other branches in the form of low-interest and interestfree loans. A company located in a country with a high level of taxation uses the funds received as its own, but formally they act as loans, and therefore the tax is not paid on them. Moreover, both the loan amount and interest money are returned after the expiration of the offshore branch. As a result, the corporation's profits are concentrated in those structures where they are not threatened by high taxes, and the formal structure of capital used by various branches is increasingly leaning towards borrowing. In practice, the funds belong to an offshore branch and are available to the entire multinational corporation.

New forms of lending in the form of interest-free intra-corporate loans for a period of 364 days are widely used by the Tax Code. On the basis of a specially calculated maturity, the receipt and repayment of the loan is reflected in one annual balance sheet. From a legal point of view, now the loan does not exist, because it does NOT have a significant impact on the balance sheet of the corporation.

No less effective is the transfer of profits from the used special methods of insurance. In this case, financial schemes are created, according to which in offshore subsidiaries are organized necessary for the planning of the firm, which insures at bequest rates all the property of the corporation. In the opposite direction, the funds are returned in the form of loans. As a result, a multinational corporation achieves stability through financial manipulation based on the presence of its number of subsidiaries in different countries [p. 190-196].

It should be noted that in the process of transnational activity of the corporation the most important role will be won not to maximize profits in the short term, but to long-term stable profits, which ultimately have a positive impact on the economy of the host country and host country 
At the sixth (final) stage of transnationalization of Ukrainian corporations and patents will assess the effect of their impact on the economy of the host country and the home country of the parent corporation.

Since foreign direct investment is currently the main form of expansion of the corporation's activity abroad, it is necessary to identify and analyze the relationship of FDI in the country's economy as a whole and in its individual industries with the success (profitability) of their operation. Based on the results of the analysis, it is necessary to qualitatively assess the effect of the presence of TNC units in the economy of the host country, and take appropriate measures to strengthen the positive and minimize negative aspects of TNCs' influence on the state and development of the host economy.

The most important problem at the final stage is the creation of a situation in which a transnational corporation would become a tool for realizing the interests of the home country in the world economy and would make positive changes in the functioning of the mother economy. In this case, it is necessary to minimize the likelihood of the phenomenon of "English disease", which results in a sharp contradiction between the active growth and development of transnational corporations and the downturn in the economy of their home country.

\section{CONCLUSION}

It is necessary to develop a system of state measures to prevent the activities of transnational corporations only in the framework of selfcorporate interest (which, in essence, is to maximize profits), aimed at creating a partnership between the host country and the multinational corporation. It is on this aspect that attention is focused in the Ukrainian legislation on promoting the process of creating financial-industrial groups.

In general, without the successful coordination of corporate and state interests in the process of creating transnational corporations in the Ukrainian economy, without the transformation of TNCs (at least in part) into a factor of sustainable development and economic growth of the host country.

In conclusion, it must be said that the formation of domestic TNCs and their further foreign expansion in the context of economic globalization can become the main driving force, which allows the country to take a leading position in modern international economic relations. The priority of economic interests of TNCs can be considered as the highest stage of integration of the national economic system into the global one

Thus, based on a schematic representation, we can conclude that the harmonization of economic interests of TNCs and the national economy of the recipient country should contribute primarily to the development of its economic system in the context of globalization, based primarily on the formation of positive transgression of economic interest from the global economy to the national with the participation of TNCs. This will allow the national economy to take advantage of globalization, position national priorities in the global economy, more clearly define national competitive advantages, forecast economic growth and prospects for the national economy, taking into account the interaction of national entities with transnational corporations based on transgression of economic interests.

\section{$\Lambda$ ітература:}

1. Смирнов С.В. Циклические колебания в рыночной экономике. Экономический журнал BШE. 2018. № 2. C. 23-28.

2. Воронин Ю. Ориентиры выхода из экономического кризиса. Экономист. 2019. № 5. С. $44-48$.

3. Губанов С. Цикличность - форма кризисности. Экономист. 2020. № 1. С. 14-17.

4. Аюбимов $\Lambda . \Lambda$. Основы экономических знаний. М.: ВИТА-ПРЕСС, 2021. С. 4-9.

5. Васильчук Ю. Воздействие семьи на динамику рыночной экономики. Мировая экономика и международные отношения. Киев, Украина. 2019. № 1. С. 36-41.

6. Воронков А.А. Методы анализа и оценки государственных программ в США. М.: Наука, 2020. 190-196 c.

\section{References:}

1. Smirnov, S.V. (2018), "Cyclical fluctuations in market economy", Ekonomicheskij zhurnal VShE, vol. 2, pp. 23-28.

2. Voronin, Y. (2019), "Landmarks exit from the economic crisis", Jekonomist, vol. 5, pp. 44-48.

3. Gubanov, S. (2020), "Cyclical - a form of crisis", Jekonomist, vol. 1, pp. 14-17.

4. Ljubimov, L.L. (2012), Osnovy jekonomicheskih znanij [Fundamentals of Economic Studies], VITA-PRESS, Moscow, Russia, pp. 4-9.

5. Vasil'chuk, Ju. (2019), Vozdejstvie sem'i na dinamiku rynochnoj jekonomiki [The impact on the family dynamics of the market economy], $\mathrm{Mi}$ rovaja jekonomika i mezhdunarodnye otnoshenija, Kyiv, Ukraine.

6. Voronkov, A.A. (2020) Metody analiza i ocenki gosudarstvennyh programm v SShA [Methods of analysis and evaluation of government programs in the US], Nauka, Moscow, Russia, pp. 190-196.

Стаття надійшла до редакиї̈ 24.05.2021 p. 